\title{
Pengembangan Bahan Ajar Matematika Realistik berbasis Alquran Pokok Bahasan Pecahan
}

\author{
Muhammad Ihsan \\ Pendidikan Matematika, Institut Agama Islam Negeri Palopo \\ e-mail: ihsan@iainpalopo.ac.id
}

\begin{abstract}
ABSTRAK. Menghubungkan matematika dengan al-quran merupakan sebuah upaya untuk menjadikan pembelajran matematika lebih bermakna dan realistis. Tujuan penelitian ini adalah mengembangkan bahan ajar berupa handout matematika realistik berbasis al-quran untuk pokok bahasan pecahan yang valid dan praktis. Penelitian ini merupakan penelitian pengembangan yang mengadopsi model ADDIE. Namun, pada penelitian ini hanya melakukan 3 tahap yaitu analisis, desain dan pengembangan. Bahan ajar yang telah dirancang divalidasi oleh tiga orang pakar yaitu ahli media, ahli desain dan ahli materi Untuk uji kepraktisan oleh siswa.Teknik pengumpulan data yang digunakan adalah melalui teknik pengumpulan data dengan menggunakan angket. Hasil analisis data menunjukkan bahwa bahan ajar matematika realistik berbasis al-quran telah valid dan praktis digunakan untuk materi pecahan.
\end{abstract}

Kata kunci : Al-quran, Bahan Ajar, Handout, Matematika Realistik, Pecahan.

\section{PENDAHULUAN}

Pecahan merupakan materi dasar dan memegang peranan penting dalam mata pelajaran matematika. Pecahan banyak dijumpai dalam materi lain seperti persamaan linear, fungsi, aljabar, geometri, kalkulus dan banyak lagi. Selain itu, operasi pecahan sering pula dijumpai dan digunakan dalam kehidupan sehari-hari, salah satunya dalam hal pembagian harta warisan. Pembahasan tentang pecahan dalam kurikulum dijumpai pada mata pelajaran matematika tingkat SD dan SMP. Matematika merupakan salah satu mata pelajaran yang wajib diajarkan pada jenjang $\mathrm{SMP} / \mathrm{MTs}$.

Pecahan merupakan salah satu konten bilangan yang diujikan dalam studi Trends in International Mathematics and Science Study (TIMSS). Mullis, Martin, Foy \& Hooper (Nurdin et al., 2019) menyatakan bahwa pada tahun 2015, rata-rata skor matematika siswa Indonesia hanya 397 poin, hanya menduduki peringkat 44 dari 49 negara partisipan. Hasil survei TIMSS menunjukkan prestasi matematika siswa Indonesia masih rendah. Salah satu unsur yang dianggap menjadi penyebab rendahnya prestasi siswa adalah kurangnya motivasi belajar. Sebagaimana yang dikatakan oleh Nur (2016) bahwa persepsi tentang matematika dan motivasi berpengaruh terhadap hasil belajar matematika rata-rata memiliki pengaruh yang cukup signifikan mencapai 30\%. Hasil penelitian Ihsan (2016) juga menunjukkan bahwa motivasi memiliki pengaruh signifikan terhadap kemampuan matematis siswa, khususnya kemampuan pemecahan masalah.

Berdasarkan hasil wawancara terbatas penulis dengan beberapa santri/siswa dan guru tentang pelajaran matematika menunjukkan bahwa rendahnya motivasi belajar menjadi masalah pokok oleh siswa. Umumnya mereka mengatakan bahwa matematika adalah ilmu umum yang cenderung hanya duniawi semata bahkan tidak memiliki hubungan dengan agama. Hal ini, tentulah tidak sepenuhnya salah, ketika membaca buku-buku pelajaran matematika yang diajarkan 
secara umum, memang kelihatannya hanya membahas sesuai anggapan para santri dan guru tersebut.

Kemungkinan lemahnya motivasi belajar matematika siswa adalah kurang tersedianya media pembelajaran atau buku matematika yang memuat atau menghubungkan matematika dengan alquran. Karena orientasi agama/alquran di kalangan pondok pesantren menjadi nomor satu. Penggunaan media yang tepat dapat meningkatkan meningkatkan pemahaman, minat dan motivasi belaajr siswa (Ayurila, Risnawati \& Nurdin, 2018). Untuk itu, dibutuhkan suatu media pembelajaran atau bahan ajar yang dapat mengaitkan memotivasi siswa, yaitu dengan mengaitkan matematika dengan alqur-an.

Salah satu contoh ayat yang menyebut tentang matematika di dalam alquran yang memuat konsep matematika adalah surah An-nisa ayat 11-12. Dalam ayat tersebut disebutkan tentang bagian-bagian harta yang diperoleh oleh ahli waris yang terdiri dari beberapa pecahan yang disebutkan diantaranya 1/2,1/3,2/3 dan seterusnya. Surah ini menggambarkan konsep pecahan dalam kehidupan nyata. Konsep yang diajarkan dalam surah ini menunjukkan tidak ada pemisah antara alquran dengan matematika.

Para pakar pendidikan Islam sependapat bahwa konsep dasar dalam pendidikan Islam adalah tauhid. Dengan dasar ini pulalah H.M. Quraish Shihab merumuskan beberapa hal diantaranya adalah kesatuan ilmu. Tidak ada pemisahan antara ilmu-ilmu agama dan ilmu-ilmu umum, karena semuanya bersumber dari satu sumber, yaitu dari Allah SWT (Fathurrahman, 2010). Alquran adalah kalam Allah yang bersifat mukjizat yang diturunkan kepada nabi Muhammad melalui perantara Jibril dengan lafal dan maknanya dari Allah SWT, yang dinukilkan secara mutawatir, membacanya merupakan ibadah, dimulai dengan surah al-Fatihah dan diakhiri dengan surah an-Nas (Shihab, 2008).

Ayat-ayat alquran berisi petunjuk-petunjuk yang berupa perintah, larangan dan anjuran, dengan tingkat kepentingan yang berbeda-beda, sehingga ada yang dikatakan sebagai wajib, sunnah dan sebagainya. Mereka yang meyakini alquran sebagai petunjuk dari Allah Yang Maha Kuasa, penguasa langit dan bumi, pencipta alam semesta, akan selalu mencari petunjuk-petunjuk dari alquran ketika mereka menghadapi berbagai masalah dalam kehidupan mereka. Dengan mengikuti petunjuk-petunjuk ini mereka kemudian akan dapat mengatasi masalah-masalah tersebut (Putra, 2012).

Matematika dan alquran merupakan bagian yang tidak terpisah dari kehidupan nyata. Pendekatan matematika dengan kehidupan nyata biasa disebut dengan matematika realistik. Berbagai hasil penelitian menunjukkan pembelajaran matematika realistik efektif meningkatkan motivasi dan hasil belajar matematika. Pembelajaran matematika dengan menggunakan pendekatan realistik/RME berpengaruh signifikan terhadap prestasi belajar dan motivasi dan prestasi belajar siswa (Sulastri \& Benedictus, 2016; Wahyuni \& Jailani, 2017; Nugroho 2018). Hasil penelitian Nopriana (2015) menyimpulkan bahwa pembelajaran dengan pendekatan pendidikan matematika realistik berbantuan bahan manipulatif berpengaruh terhadap motivasi belajar siswa. Hal ini dapat dilihat dari hasil belajar matematika yang meningkat, siswa lebih tertarik terhadap matematika dan lebih aktif dalam proses pembelajaran. Hal ini didukung oleh hasil penelitian Suwoto (2015) yang memperlihatkan respon positif siswa terhadap pembelajaran matematika realistik.

Beberapa peneliti telah menerapkan pembelajaran matematika berbasis alquran. Gradini, Wahyuni \& Ansor (2017) menyimpulkan bahwa pembelajaran matematika qur'ani efektif diterapkan pada Madrasah Tsanawiyah di Aceh Tengah. Berbagai bahan ajar matematika berbasis alquran telah dirancang oleh para peneliti. Sadieda \& Rifatin (2015) telah merancang perangkat pembelajaran matematika dengan memasukkan nilai-nilai islami pada materi pokok bilangan bulat di kelas IV MI Mambaul Ulum Terik Krian Sidoarjo yang valid, praktis dan efektif.

Pada penelitian ini peneliti mengembangkan suatu bahan ajar berupa handout yang memadukan matematika realistik dan konsep alquran pokok bahasan pecahan untuk siswa kelas 
VII Madrasah Tsanawiyah/Pondok Pesantren. Tujuan penelitian ini adalah mengembangkan bahan ajar matematika realistik berbasis alquran yang valid dan praktis.

\section{METODE}

Penelitian ini merupakan penelitian pengembangan (research and development). Model pengembangan yang digunakan diadaptasi dari ADDIE Model yang prosedurnya terdiri atas 5 langkah, yaitu (1) analisis (analyze), (2) Perancangan (design), (3) pengembangan (development), (4) Implementasi (implementation) dan (5) evaluasi (evaluation). Karena keterbatasan waktu dan biaya, maka penelitian ini terhenti pada tahap ke 3 yaitu pengembangan.

Penelitian ini dilaksanakan di Madrasah Tsanawiyah Negeri Palopo, Sulawesi Selatan. Instrumen pengumpulan data yang digunakan pada penelitian ini adalah angket. Angket dipergunakan untuk mengumpulkan data hasil review dari guru dan pakar. Angket yang digunakan dalam penelitian ini adalah angket yang telah dikembangkan oleh I Made Tegeh.

Data yang diperoleh melalui angket selanjutnya diolah dengan deskriptif persentase. Rumus yang digunakan yaitu (Sudijono, 2011):

$$
p=\frac{\sum x}{s m} \times 100 \%
$$

Keterangan:

$P=$ Angka Persentase

$\sum x=$ Jumlah Skor

$s m=$ Skor Maksimal

Untuk penilaian kevalidan bahan ajar yang dikembangkan, digunakan kriteria penilaian yang diadaptasi dari Arikunto (2010), dapat dilihat pada Tabel 1. Untuk penilaian kepraktisan bahan aajar digunakan kriteria yang diadaptasi dari Akbar (2013), dapat dilihat pada Tabel 2.

Tabel 1. Kriteria Penilaian data persentase Validitas Bahan Ajar

\begin{tabular}{cc}
\hline Persentase $(\%)$ & Kriteria \\
\hline $90 \leq p \leq 100$ & Sangat Valid \\
$70 \leq p<90$ & Valid \\
$50 \leq p<70$ & Cukup Valid \\
$30 \leq p<50$ & Kurang Valid \\
$0 \leq p<30$ & Tidak Valid \\
\hline
\end{tabular}

Tabel 2. Kriteria Penilaian data persentase Kepraktisan Bahan Ajar

\begin{tabular}{cc}
\hline Persentase $(\%)$ & Kriteria \\
\hline $85 \leq p \leq 100$ & Sangat Praktis \\
$70 \leq p<85$ & Praktis \\
$50 \leq p<70$ & Cukup Praktis \\
$0 \leq p<50$ & Kurang Praktis \\
\hline
\end{tabular}

\section{HASIL DAN PEMBAHASAN}

Sebagaimana telah disebutkan sebelumnya bahwa penelitian ini hanya sampai pada tahap ketiga model pengembangan ADDIE. Adapun tahapan pengembangan yang dilakukan adalah analyze, design dan development. Berikut diuraikan hasil pengembangan yang dilakukan pada setiap tahap.

\section{Tahap Analyze}

Pada tahap ini, peneliti melakukan analisa terhadap kompetensi, materi yang akan dimuat dalam bahan ajar dan karakteristik siswa yang akan menggunakan bahan ajar ini,. Kompetensi inti dan kompetensi dasar (lihat Tabel 3) yang diharapkan disesuaikan dengan kurikulum 2013 (Menteri Pendidikan dan Kebudayan, 2016). Kompetensi inti yang diharapkan adalah sebagai berikut: 
KI-1 : Menghargai dan menghayati ajaran agama yang dianutnya.

KI-2 : Menghargai dan menghayati perilaku jujur, disiplin, tanggung jawab, peduli (toleransi, gotong royong), santun, percaya diri, dalam berinteraksi secara efektif dengan lingkungan sosial dan alam dalam jangkauan pergaulan dan keberadaannya.

KI-3 : Memahami pengetahuan (faktual, konseptual, dan prosedural) berdasarkan rasa ingin tahunya tentang ilmu pengetahuan, teknologi, seni, budaya terkait fenomena dan kejadian tampak mata.

KI-4 : Mencoba, mengolah, dan menyaji dalam ranah konkret (menggunakan, mengurai, merangkai, memodifikasi, dan membuat) dan ranah abstrak (menulis, membaca, menghitung, menggambar, dan mengarang) sesuai dengan yang dipelajari di sekolah dan sumber lain yang sama dalam sudut pandang/teori.

\section{Tabel 3. Kompetensi Dasar dan Indikator Pencapaian}

Kompetensi dasar

3.2 Menjelaskan dan melakukan operasi hitung bilangan bulat dan pecahan dengan memanfaatkan berbagai sifat operasi
Indikator Pencapaian

1. Siswa mampu menjelaskan definisi Pecahan

2. Siswa mampu memahami Pecahan yang ada dalam Alquran

3. Siswa mampu memahami pecahan senilai

4. Siswa mampu Melakukan penjumlahan dan pengurangan Pecahan

5. Siswa mampu Melakukan Perkalian Pecahan

6. Siswa mampu Melakukan Pembagian Pecahan

4.1 Menyelesaikan masalah yang berkaitan dengan operasi hitung bilangan bulat dan pecahan
Siswa mampu menyelesaikan masalah sehari hari yang melibatkan pecahan

Kompetensi yang paling utama diharapkan pada materi pecahan adalah siswa mampu memahami definisi tentang bilangan pecahan serta melakukan operasi $(+,-, \mathrm{x},:)$ yang melibatkan bilangan pecahan dan mampu menggunakan operasi tersebut dalam memecahkan masalah seharihari. Di dalam alquran ditemukan beberapa ayat yang menyebutkan pecahan yaitu yang berbicara tentang syariat pelaksanaan pembagian harta warisan. Hal ini menjadikan materi pecahan yang begitu penting untuk dipahami dan diamalkan.

Setelah menganalisa kompetensi apa saja yang diharapkan, maka selanjutnya peneliti melakukan analisa terhadap karakteristik siswa yang akan menggunakan bahan ajar ini. Peneliti melakukan wawancara kepada guru dan siswa pondok pesantren. Dari wawancara tersebut diperoleh kesimpulan bahwa bahkan kepedulian santri pondok pesantren terhadap mata pelajaran matematika masih rendah, matematika dianggap hanyalah mata pelajaran yang kurang penting sehingga kadang kurang diperhatikan. Hal ini tentunya menjadi salah satu penyebab sehingga siswa kurang termotivasi dan berminat untuk belajar matematika. Dengan stigma bahwa matematika hanyalah merupakan pelajaran umum yang tidak mempunyai hubungan dengan agama/alquran, menjadikan pelajaran matematika menjadi pelajaran paling dihindari dan kurang diminati. Oleh sebab itu, dibutuhkan suatu bahan ajar matematika yang menghubungkan atau mengaitkan materi matematika dengan apa yang ada pada ayat-ayat alquran sehingga diharapkan mampu menambah minat dan motivasi siswa untuk lebih tekun belajar matematika.

Dengan bahan ajar pecahan berbasis alquran ini menggunakan pendekatan realistik diharapkan dapat mengatasi persepsi negatif terhadap matematika serta meningkatkan motivasi belajar matematika. Matematika tidak lagi dianggap sebagai mata pelajaran yang tidak memiliki hubungan dengan alquran yang menjadi sumber petunjuk bagi seluruh makhluk di dunia ini. bahan ajar ini, para guru dan siswa akan terbantu dalam proses pembelajaran karena lebih terarah. 


\section{Tahap Design}

Setelah melakukan tahapan analisis, peneliti melanjutkan dengan mendesain bahan ajar matematika realistik berbasis alquran. Pada tahapan ini peneliti mengumpulkan referensi yang akan dijadikan bahan penyusunan/pengembangan bahan ajar pecahan berbasis alquran, berdasarkan pertimbangan analisis-analisis yang dilakukan pada tahap analisis sebelumnya. Selain itu, peneliti juga mengumpulkan gambar maupun ilustrasi dan contoh-contoh soal yang relevan dan diperoleh dari berbagai sumber di internet melalui penelusuran google. Hal ini dilakukan untuk menunjang tampilan dan memperjelas ilustrasi dan menambah visual serta diharapkan menjadi daya tarik bagi pembaca, sehingga meningkatkan minat dan motivasi untuk mempelajarinya. Kemudian dilanjutkan dengan pengetikan naskah, pembuatan gambar atau pengembangan draft awal.

Garis besar isi dari bahan ajar yang dikembangkan, penulis gambarkan dalam peta konsep seperti pada Gambar 1 dan tampilan awal dari desain yang peneliti rancang dapat dilihat pada Gambar 2 dan 3.

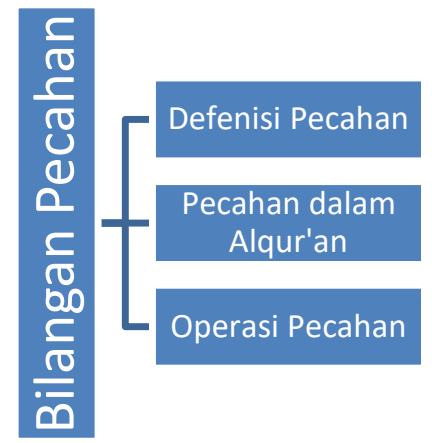

Gambar 1. Peta Konsep Bahan Ajar
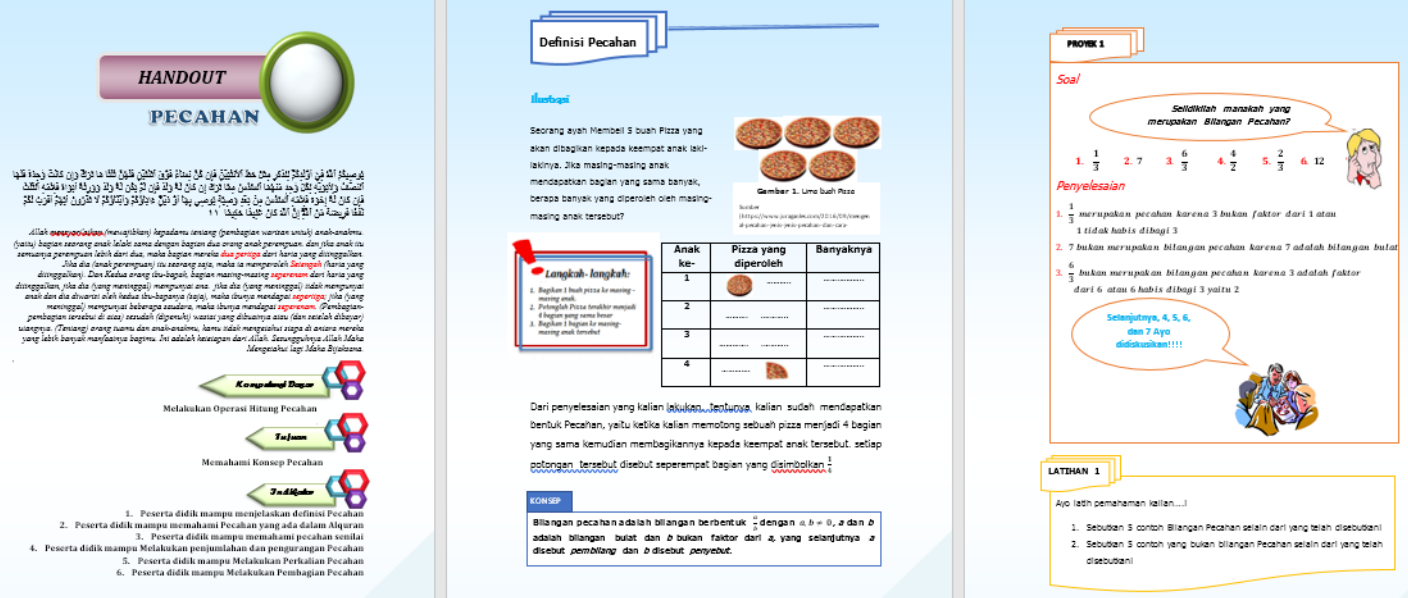

Gambar 2. Desain Isi 1 


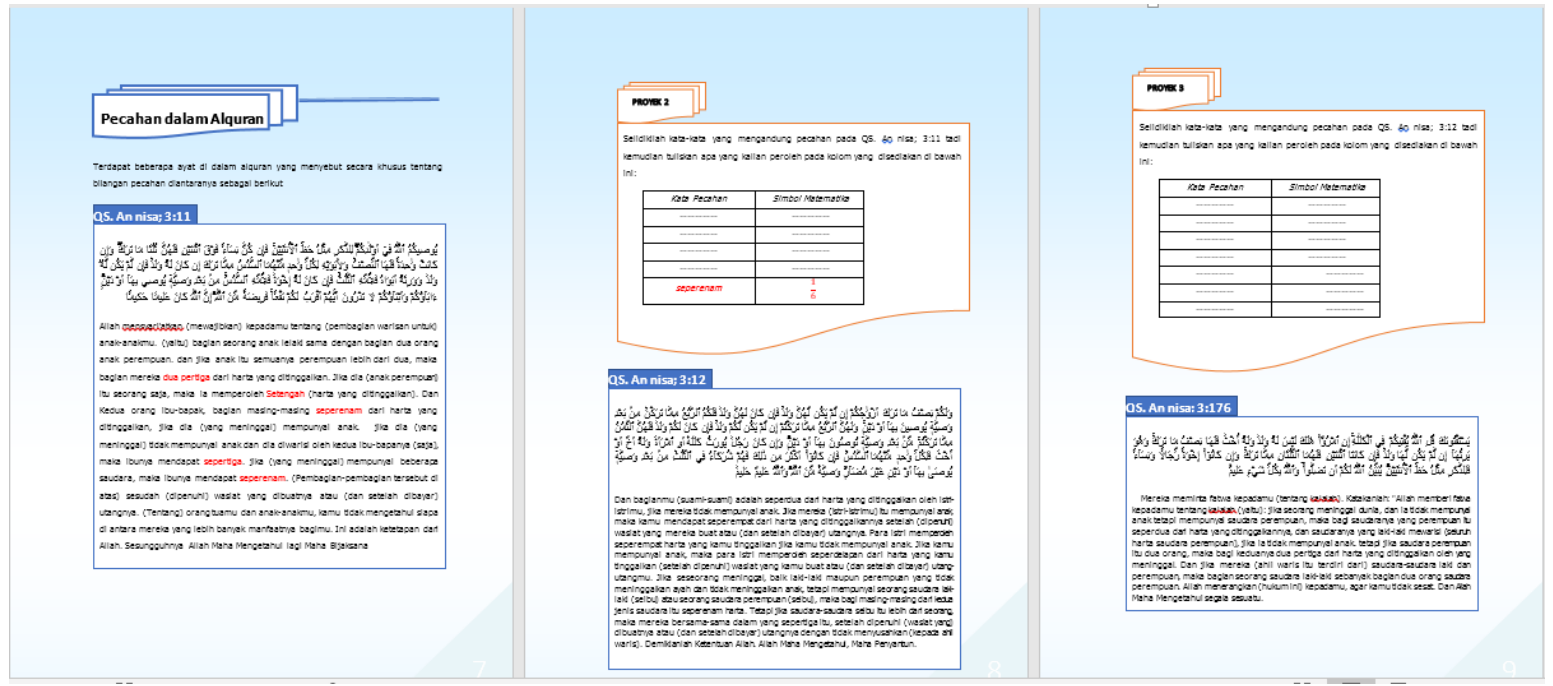

Gambar 3. Desain Isi 2

\section{Tahap Development}

Pada tahapan ini, peneliti melakukan uji terhadap kevalidan dan bahan ajar yang dikembangkan. Bahan ajar yang telah dikembangkan divalidasi oleh 3 orang ahli, yaitu ahli media, desain dan materi. Validator media dan desain yang dipilih pada penelitian ini adalah seorang dosen yang dipandang cakap dengan latar belakang penelitiannya dari pengembangan media yang juga mengampu mata kuliah media pembelajaran dan desain pembelajaran. Hasil uji validasi media dan desain dapat dilihat pada tabel berikut:

Tabel 4. Hasil Validasi Media dan Desain

\begin{tabular}{llcccc}
\hline No & \multicolumn{1}{c}{ Aspek Penilaian } & \multicolumn{3}{c}{ Hasil Penilaian } \\
& & $\begin{array}{c}\text { Validator } \\
\text { Media }\end{array}$ & Kriteria & $\begin{array}{c}\text { Validator } \\
\text { Desain }\end{array}$ & Kriteria \\
\cline { 3 - 6 } & & 87.5 & Valid & 75 & Valid \\
2 & Teknik Penyajian & 87.5 & Valid & 85 & Valid \\
3 & Kelayakan Penyajian & 85 & Valid & 77.5 & Valid \\
3 & Kelayakan Kegrafikan & 87.5 & Valid & 87.5 & Valid \\
4 & Komunikatif & 75 & Valid & 75 & Valid \\
5 & Kesesuaian dengan & & & & \\
& Tingkat Perkembangan & & & & \\
& Siswa & & &
\end{tabular}

Kemudian, untuk validasi materi, validator ahli pada penelitian ini adalah seorang guru matematika yang sudah puluhan tahun mengajar di MTs/Pondok Pesantren dan aktif dalam kegiatan kegiatan pelatihan pembelajaran matematika. Hasil uji validitas materi dapat dilihat pada tabel berikut:

Tabel 5. Hasil Validasi Materi

\begin{tabular}{llcc}
\hline No & \multicolumn{1}{c}{ Aspek Penilaian } & \multicolumn{2}{c}{ Hasil Penilaian } \\
& & Persentase & Krteria \\
\cline { 3 - 4 } 1 & Kesesuaian Uraian Materi dengan SK dan KD & 66.67 & Cukup Valid \\
2 & Keakuratan Materi & 80 & Valid \\
3 & Materi Pendukung & 68.75 & Cukup Valid \\
4 & Kemutakhiran Materi & 91 & Sangat Valid \\
5 & Mendorong Keingintahuan & 75 & Valid \\
6 & Kesesuaian Materi dengan Karakteristik Realistik & 75 & Valid \\
\hline
\end{tabular}

Dapat dilihat pada Tabel 3, bahwa dari segi media dan desain, bahan ajar yang dirancang telah valid. Sedangkan dari segi materi masih terdapat komponen yang hanya mencapai kategori 
cukup valid. Untuk itu, perlu dilakukan revisi sesuai dengan saran dan masukan dari para validator. Saran dan masukan yang diberikan validator diantaranya adalah.

1) Point $1.1 / 2$ sebaiknya di tulis 1) $1 / 2$ agar jelas penomorannya.

2) Pada point Latihan 2 tidak usah diberi no 3 karena bukan sambungan, tetapi cukup hilangkan saja nomor di bagian soal.

3) Pada point Penyelesaian 4,5,6 dan 7 ada point didiskusikan namun tidak ada lembar penyelesaian hasil diskusi para siswa. Sebaiknya dibuatkan agar ada hasil akhir dari diskusi siswa tersebut dan guru mampu mengoreksi letak kekeliruan siswa tersebut.

4) Pada penyelesaian soal sebaiknya kata $1 / 2$ dari 4 diberi konsep bahwasanya $\frac{1}{2} \times 4=\frac{4}{2}=2$. Jadi, Rusdi mendapatkan 2 buah.

5) Ikon Gambar usahkan berbeda di setiap langkah, guna mendapatkan daya tarik tersendiri.

6) Sebaiknya setiap gambar dilengkapi dengan keterangan

7) Penggunaan kata "selidikilah" diganti menjadi "carilah".

Setelah melakukan validasi dan merevisi bahan ajar berdasarkan penilaian validator, selanjutnya peneliti melakukan uji praktikalitas. Untuk menguji praktikalitas bahan ajar yang dikembangkan, dilakukan pengisian angket oleh siswa. Namun sebelumnya, terlebih dahulu para siswa dibagikan cetakan bahan ajar tersebut untuk dibaca dan dipelajari. Pembelajaran dengan menggunakan rancangan bahan ajar ini dilakukan selama satu hari dengan pertimbangan menyesuaikan dengan alokasi waktu yang sebenarnya untuk materi pecahan. Dalam pembelajaran ini, peneliti dibantu oleh pembantu lapangan serta guru kelas tempat penelitian.

Setelah pembelajaran selesai dan siswa istirahat, para siswa mengisi angket untuk melihat respon siswa terhadap bahan ajar yang dikembangkan. Berdasarkan hasil pemeriksaan angket respon siswa, dari 34 orang siswa yang hadir terdapat 3 buah angket yang tidak diisi sama sekali, sehingga diambil keputusan hanya 31 angket yang dianalisis untuk pertimbangan perhitungan praktikalitas bahan ajar. Hasil uji kepraktisan bahan ajar tergambar pada tabel berikut:

Tabel 6. Hasil Respon Siswa

\begin{tabular}{llcc}
\hline No & \multicolumn{1}{c}{ Aspek Penilaian } & \multicolumn{2}{c}{ Hasil Penilaian } \\
& & Persentase & Kriteria \\
\cline { 3 - 4 } 1 & Aspek Grafik & 70.36 & Praktis \\
2 & Aspek Pengembangan Materi & 70.32 & Praktis \\
3 & Aspek Linguistik & 64.52 & Cukup Praktis \\
4 & Aspek Manfaat & 71.98 & Praktis \\
\hline
\end{tabular}

Berdasarkan hasil uji praktikalitas, dapat dilihat bahwa masih terdapat aspek yang hanya masuk kategori cukup praktis, yaitu aspek linguistik. Untuk itu, bahan ajar ini masih perlu direvisi dari segi bahasa atau kalimat yang digunakan. Namun, secara umum bahan ajar matematika realistik berbasis alquran yang dirancang sudah dapat dikatakan praktis dan layak digunakan untuk materi pecahan.

\section{KESIMPULAN}

Berdasarkan hasil penelitian dan analisi data, maka bahan ajar matematika realistik berbasis alquran valid dan praktis digunakan untuk materi pecahan kelas VII MTs/Pondok Pesantren.

\section{DAFTAR PUSTAKA}

Akbar, S. (2013). Instrumen perangkat pembelajaran. Bandung: PT Remaja Rosdakarya.

Arikunto, S. (2010). Prosedur penelitian: suatu pendekatan praktik. Jakarta: PT Rineka Cipta.

Ayurila, M., Risnawati., \& Nurdin, E. (2018). Pengembangan lembar kerja siswa berbasis group investigation untuk memfasilitasi kemampuan penalaran matematis siswa. Juring: Joournal for 
Research in Mathematics Learning, 1(3), 219-226.

Fathurrahman, P. (2010). Strategi belajar maengajar: strategi mewnjudkan pembelajaran bermakna melalui konsep umum \& islami. Bandung: PT Refika Aditama.

Gradini, E., Wahyuni, S., \& Ansor. (2017). Efektifitas penerapan pembelajaran matematika qur'ani dalam pembelajaran himpunan. Al Khawarizmi: Jurnal Pendidikan dan Pembelajaran Matematika, 1(1), 1-20.

Ihsan, M. (2016). Pengaruh metakognisi dan motivasi terhadap kemampuan pemecahan masalah matematika melalui kreativitas siswa kelas VIII SMP Negeri di Kecamatan Kindang Kabupaten Bulukumba. Jurnal Pendidikan Matematika dan Ilmu Pengetahuan Alam, 4(2), 129140. DOI: https://doi.org/10.18848/1447-9494/CGP/v15i03/45692.1.

Menteri Pendidikan dan Kebudayan. (2016). Peraturan menteri pendidikan dan kebudayaan nomor 21 tahun 2016 tentang standar isi pendidikana dasar dan menengah. Tersedia di http://bsnpindonesia.org/wp-

content/uploads/2009/06/Permendikbud Tahun2016_Nomor021_Lampiran.pdf

Nopriana, T. (2015). Pengaruh pendekatan matematika realistik berbantuan bahan manipulatif terhadap motivasi belajar matematika. Fibonacci: Jurnal Pendidikan Matematika \& Matematika, 1(2), 80-94.

Nugroho, M. H. (2018). Penerapan model pembelajaran realistic mathematics education (RME) untuk meningkatkan motivasi dan prestasi belajar matematika materi statistika pada siswa kelas XI TP3RP SMK Negeri 1 Kendal tahun pelajaran 2015/2016. Journal of Medives: Journal of Mathematics Education IKIP Veteran Semarang, 2(2), 213-223.

Nur, M. A. (2016). Pengaruh perhatian orang tua, konsep diri, persepsi tentang matematika terhadap hasil belajar matematika melalui motivasi. Jurnal Matematika dan Pembelajaran, 2(2), 64-79.

Nurdin, E, et al,. (2019). Pemanfaatan video pembelajaran berbasis Geogebra untuk meningkatkan kemampuan pemahaman konsep matematis siswa SMK. Jurnal Riset Pendidikan Matematika, 6(1).

Putra, H. S. A. (2012). The living al-qur'an: beberapa perspektif antropologi. Jurnal Walisongo, 20(1), 235-260.

Sadieda, L. U., \& Rifatin, A. (2015). Pengembangan pembelajaran matematika dengan memasukkan nilai-nilai islami pada materi bilangan bulat. JPM: Jurnal Pendidikan Matematika, 1(2), 168-182.

Shihab, M. Q. (2008). Sejarah dan ulum al-qur'an. Jakarta: Pustaka Firdaus.

Sudijono, A. (2011). Pengantar statistik pendidikan. Jakarta: PT Raja Grafindo Persada.

Sulastri., \& Benedictus, K. (2016). Upaya meningkatkan motivasi dan prestasi belajar matematika melalui model RME siswa Kelas IX A SMP Negeri 04 Bumi Ayu. Union: Jurnal Pendidikan Matematika, 4(3), 461-472.

Suwoto. (2015). Peningkatan motivasi belajar melalui pembelajaran matematika realistik pada siswa kelas IX SMP Negeri 1 Sumbergempol Kabupaten Tulungagung. Dinamika, 15(1), 105-116.

Wahyuni, N. D., \& Jailani, J. (2017). Pengaruh pendekatan matematika realistik terhadap motivasi dan prestasi belajar siswa SD. Jurnal Prima Edukasia, 5(2), 151-159. 